\title{
A liberdade religiosa na Declaração Dignitatis humanae: elementos para uma nova teologia das religióes e para uma inserção da religião no espaço público
}

\section{The religious freedom in the Declaration Dignitatis Humanae: elements for a new theology of religions and insertion of religion in public space}

Paulo Sérgio Lopes Gonçalves Alexandre Boratti Favretto

\section{Resumo}

Objetiva-se apresentar o processo de gênese e desenvolvimento do tema da liberdade religiosa definido na Declaração Dignitatis humanae. Esse tema não surge metodologicamente previsto pelos esquemas no Concílio Vaticano II, mas durante o processo de debates nas Congregações Gerais e se desenvolvendo nos aspectos formais, significado e fundamentação, e material adquirindo status de Declaração. Metodologicamente, faz-se uma análise fenomenológica que desemboca na hermenêutica histórica e teológica dos principais acontecimentos dos períodos conciliares preparatórios e das quatro Sessões do Concílio Vaticano II, bem como, de documentos do Magistério eclesiástico dos séculos XIX e XX que abordaram o tema da liberdade religiosa sob a perspectiva de intolerância à pluralidade religiosa e tolerância religiosa prática, superadas pelo princípio de direito à liberdade religiosa, expresso na Dignitatis humanae. Enquanto conteúdo doutrinal, o direito a liberdade religiosa passa a ter fundamento na dignidade humana, dado antropológico, que se desdobra do teológico e doutrinário e prospecta uma nova compreensão do fenômeno do pluralismo religiosa possibilitando 
conceber a teologia das religiões como teologia do pluralismo religioso e teologia hermenêutica inter-religiosa, bem como assegura a relevância das religiões nos debates do espaço público, sendo este um direito tutelado e promovido pelo Estado democrático.

Palavras-chave: Concílio Vaticano II. Declaração Dignitatis humanae. Liberdade religiosa. Dignidade da pessoa humana. Pluralismo religioso.

\begin{abstract}
The objective is to present the genesis process of the theme religious liberty defined in the Declaration Dignitatis humanae. This topic does not arise methodologically provided by schemes in the Vatican Council II, but during the process of debates in the General Congregations and developing itself in the formal aspects, meaning and foundation, and material acquiring the status of the Declaration. Methodologically, it is a phenomenological analysis that ends at the historical and theological hermeneutics of the main events of the preparatory conciliates periods and the four Sessions of the Vatican Council II, as well as, of documents of the Ecclesiastical magisterium of the centuries XIX and XX, which approached the theme of religious freedom from the perspective of religious plurality intolerance and practical religious tolerance, overcome by the principle of the religious freedom right, expressed in the Dignitatis humanae. As a doctrinal content, the right to religious freedom gets onto the fundament of the human dignity, anthropological data, which opens out to theological and doctrinaire and prospect a new understanding of the phenomenon of religious plurality enabling conceive the theology of the religions as theology of religious pluralism and hermeneutic theology interfaith, as well as ensures the relevance of religious in the public sphere debates, being this one a tutored right and promoted by the democratic State.
\end{abstract}

Keywords: Vatican Council II. Declaration Dignitatis humanae. Religious liberty. Dignity of the human being. Religious pluralism. 


\section{Introdução}

A sociedade contemporânea está envolta pelo pluralismo religioso, realidade irrenunciável e passível de compreensão para que se evitem os fundamentalismos e intolerâncias religiosas. Saber o que a Igreja Católica entende por liberdade religiosa, sobretudo para o ocidente cristão, contribui significativamente para uma nova e ampla concepção da livre prática da religião e inaugura a perspectiva de que a liberdade religiosa, por estar fundamentada na dignidade da pessoa humana, é o apogeu de todas as liberdades e núcleo essencial dos direitos humanos. Para tanto, o documento do Magistério eclesiástico que define e apresenta a fundamentação do tema é a Declaração do Concílio Vaticano II Dignitatis humanae. Identificando a importância do tema da liberdade religiosa e o documento que o localiza na Igreja Católica, estampamos o nosso objetivo: apresentar e analisar epistemologicamente o processo de gênese histórico e doutrinal do tema da liberdade religiosa definido na Declaração Dignitatis humanae do Concílio Vaticano II, estabelecer sua definição conceitual e apresentar o debate sobre este tema.

A relevância do estudo se dá ante a complexidade do campo de análise que envolve o processo de redação e estruturação do texto da Declaração Dignitatis humanae e do tema da liberdade religiosa, por ela apresentado. Trata-se de desvelar como questões fundamentais o desenvolvimento de uma doutrina e sua continuidade com a Tradição teológica do Magistério eclesiástico ${ }^{1}$ e a própria questão histórica da liberdade em geral, presente tanto na liberdade de consciência quanto na liberdade religiosa, configurando-a como a liberdade das liberdades ${ }^{2}$. Além disso, a análise do tema é inserida em uma perspectiva não só teológica, mas antropológico-filosófica, apresentando doutrinariamente a concepção de liberdade religiosa fundamentada na dignidade da pessoa humana enquanto fundamento antropológico, que se desdobra do teológico

\footnotetext{
${ }^{1}$ Cf. O’MALLEY, John W. O que aconteceu no Vaticano II. São Paulo: Loyola, 2014, pp. 20-25. Não obstante a possibilidade de interpretação mediante a dialética continuidade-descontinuidade optou-se neste artigo pela compreensão da dialética entre a continuidade e a mudança, considerando que "os dezesseis documentos finais do Concílio não dão o sentido de antes e depois, nem indicam, exceto ocasionalmente, de maneira afável, que o que dizem muda alguma coisa que antes parecia normativa" (p.21).

${ }^{2}$ Cf. Bento XVI. "Exortação Apostólica Pós-Sinodal Ecclesia in Medio Oriente", n. 26, 14 de setembro de 2012. Disponível em: <http://w2.vatican.va/content/benedict-xvi/pt/apost_exhortations/documents/hf_ben-xvi_exh_20120914_ecclesia-in-medio-oriente.html>. Acesso em 28 de outubro 2015. "A liberdade religiosa é o apogeu de todas as liberdades".
} 
e doutrinário. Esta afirmação apresenta-se como realidade inédita e também prospectiva, ao apresentar elementos que possibilitam uma teologia das religiões que se configure como teologia do pluralismo religioso.

Metodologicamente, utiliza-se a análise fenomenológica ao mostrar o processo de desenvolvimento do tema da liberdade religiosa, que desemboca na hermenêutica histórica e teológica dos períodos conciliares, bem como de documentos do Magistério eclesiástico dos séculos XIX e XX que trataram do tema, compreendendo o itinerário de elaboração da Declaração Dignitatis humanae articulado também ao conjunto de escritos do Concílio Vaticano II, que tratam da temática referente ao diálogo com o mundo moderno e entre as distintas tradições religiosas e as pessoas sem religião. Estabelecem-se, portanto, os pressupostos epistemológicos e doutrinais, e as influências histórico-contextuais que antecederam e possibilitaram o tema da liberdade religiosa no Concílio Vaticano II. Expõe-se a dinamicidade das concepções eclesiásticas oficiais da Igreja Católica, enquanto caráter próprio à Tradição magisterial, mediante a concepção de uma "hermenêutica da reforma" ser comumente aceita pelos bispos durante o Concílio ${ }^{4}$. Analisa-se a originalidade do conteúdo da Declaração Dignitatis humanae: o direito à liberdade religiosa a partir da constatação teológico-antropológica da dignidade humana e se desenvolve, enquanto desdobramentos histórico-religiosos e jurídicos, a

\footnotetext{
${ }^{3}$ Cf. Bento XVI. "Discurso aos Cardeais, Arcebispos e Prelados da Cúria Romana na Apresentação dos Votos de Natal”, 22 de dezembro de 2005. Disponível em: <http://migre.me/cb7lm>. Acesso em 28 out. 2015. "tudo depende da justa interpretação do Concílio ou, como diríamos hoje, da sua correta hermenêutica, da justa chave de leitura e de aplicação. Os problemas da recepção derivaram do fato de que duas hermenêuticas contrárias se embateram e disputaram entre si. Uma causou confusão, a outra, silenciosamente mas de modo cada vez mais visível, produziu e produz frutos. Por um lado, existe uma interpretação que gostaria de definir "hermenêutica da descontinuidade e da ruptura"; não raro, ela pôde valer-se da simpatia dos mass media e também de uma parte da teologia moderna. Por outro lado, há a "hermenêutica da reforma", da renovação na continuidade do único sujeito-Igreja que o Senhor nos concedeu; é um sujeito que cresce no tempo e se desenvolve, permanecendo porém sempre o mesmo, único sujeito do Povo de Deus a caminho. A hermenêutica da descontinuidade corre o risco de terminar numa ruptura entre a Igreja pré-conciliar e a Igreja pós-conciliar. Ela afirma que os textos do Concílio como tais ainda não seriam a verdadeira expressão do espírito do Concílio". Ratzinger, no último ano de seu pontificado, por ocasião da abertura do Ano da Fé, trouxe outros elementos de compreensão de sua hermenêutica conciliar. Cf. Bento XVI. "Texto inédito publicado por ocasião do $50^{\circ}$ aniversário do Concílio Vaticano II". Disponível em: $<$ http:// migre.me/e29PA> . Acesso em 28 out. 2015. Não obstante as críticas a esta postura hermenêutica "da reforma", da continuidade, adotar-se-á esta perspectiva nesse artigo, uma vez que a Declaração Dignitatis humanae foi redigida sob esta égide.

${ }^{4}$ Cf. O’MALLEY, John W. O que aconteceu no Vaticano II, pp. 20-21.
} 
afirmação do direito inalienável da pessoa humana em seguir os ditames de sua consciência em matéria religiosa, bem como estabelece que o Estado de direito democrático tenha a função de tutelar a liberdade religiosa e promovê-la, garantindo assim a presença e contribuição das religiões nos debates do espaço público.

$\mathrm{O}$ artigo se estrutura de maneira sistemática em três itens. $\mathrm{O}$ primeiro apresenta a contextualização geral da questão que envolve as concepções teológicas referentes ao tema da liberdade religiosa ao retomar analiticamente o contexto e os documentos do Magistério eclesiástico oitocentista e novecentista, fontais à Declaração Dignitatis humanae. O segundo item desenvolve a concepção de liberdade religiosa no contexto do Concílio Vaticano II, dando enfoque ao conteúdo desse tema que é apresentado na Declaração Dignitatis humanae: a liberdade religiosa fundamentada na dignidade humana, a autonomia da consciência e a não coação. $O$ terceiro item apresenta alguns desdobramentos histórico-religiosos, inferidos do próprio texto da Declaração Dignitatis humanae, enfatizando a apresentação de questões ainda em aberto, tais como a possibilidade de uma teologia hermenêutica inter-religiosa e o lugar da religião no espaço público, garantida e tutelada pelo Estado, emergentes do próprio tema da liberdade religiosa manifesto na Declaração Dignitatis humanae.

\section{O tema da liberdade religiosa no contexto dos documentos do Magistério eclesiástico precedentes à Declaração Dignitatis humanae}

Compreender o tema da liberdade religiosa implica necessariamente que se analise hermeneuticamente a Declaração Dignitatis humanae, por ser este o documento de referência à compreensão do conceito de liberdade religiosa fundamentado na dignidade da pessoa humana e também por ser reconhecido teologicamente à luz da Revelação divina. Dado que consequentemente prospecta um tríplice diálogo: ecumênico, inter-religioso e com os sem religião, em suma, com todas as pessoas de "boa vontade", bem como na postura exigida do Estado em sua relação com a realidade concreta do pluralismo religioso. A análise fenomenológica dessa Declaração revela que o tema da liberdade religiosa não está isento de um processo histórico-doutrinal que o antecede, ou seja, o tema não é novo, contudo pela primeira vez é tratado em Concílio e distingue-se das temáticas estritamente teológicas. A originalidade do tema é esta: o direito à liberdade religiosa, enquanto conceito técnico-jurídico, que se 
forja progressivamente partir da constatação teológico-antropológica da dignidade humana, o que é próprio do tempo moderno e secular.

O próprio texto da Declaração cita alguns documentos do Magistério eclesiástico dos séculos XIX e XX, constantes em nota, a título de fundamentação ao tema, alocando-o no contexto maior dos documentos oficiais da Igreja Católica ${ }^{5}$. O aprofundamento da compreensão fenomenológica do tema exige a pesquisa do processo de elaboração da Declaração Dignitatis humanae e do desenvolvimento do tema da liberdade religiosa nas próprias Atas do Concílio Vaticano II $^{6}$. Dentre as Congregações Gerais que abarcaram o debate entre os padres conciliares sobre o tema da liberdade religiosa, paradigmática à compreensão da "evolução histórica" dessa doutrina foi a de número 70 . Nesta, o Relator oficial do tema, o bispo de Brugge Emílio De Smedt, no intuito de apresentar o tema da liberdade religiosa em termos de uma "evolução", ou desfecho, de um longo processo que o possibilitou emergir no Concílio Vaticano II, resgata e cita documentos pontifícios oitocentistas e do século XX que trataram esta temática em distintas perspectivas, parecendo até condenar tal liberdade ${ }^{7}$. Para sanar este mal entendido De Smedt apresenta, de maneira breve, uma análise histórica e teológica para reta compreensão de como o tema da liberdade religiosa foi sendo tratado nos documentos da Igreja nestes períodos. Análise esta que é aqui ampliada e aprofundada.

\footnotetext{
${ }^{5}$ São eles: Leão XIII, "Encíclica Libertas praestantissimum" e "Encíclica Imortale Dei”; Pio XI, "Encíclica Mit brennender Sorge"; Pio XII, "Radiomensagem de 24 dez. 1944 e de 24 dez. 1942" e "Alocução Ci riesce"; João XXIII, "Encíclica Pacem in terris" e "Encíclica Mater et Magistra"; Paulo VI, "Encíclica Ecclesiam suam”. In: DENZINGER, Heinrich. Compêndio dos símbolos, definições e declarações de fé e moral. São Paulo: Paulinas: Edições Loyola, 2007.

${ }^{6}$ KLOPPENBURG, B. Concílio Vaticano II. v. 1, p. 35. Este autor, perito do Concílio Vaticano II, nos quatro volumes de sua obra apresenta a reprodução compilada e autorizada das Atas do Concílio Vaticano II. Sua autenticidade é ainda atestada, quando ele mesmo afirma, no prefácio do volume IV de sua obra, que os textos, dentre eles os referentes ao tema da liberdade religiosa, são reproduzidos de fontes autênticas e seguras, como La Documentation Catholique e também do boletim oficial do Concílio, ou mesmo de publicações da imprensa digna de fé, como a La Civiltá Cattolica e La Croix.

${ }^{7}$ Cf. Idem. Concílio Vaticano II, v. 3, pp. 319-323. Durante a $70^{\circ}$ Congregação Geral, De Smedt cita as Cartas Encíclicas Mirari vos arbitramur, Quanta cura e Syllabus errorum modernorum, dos Papas Gregório XVI e Pio IX respectivamente. Logo após, As Cartas Encíclicas de Leão XIII, Immortale Dei e Libertas praestantissimum, foram caracterizadas por De Smedt como o início da evolução doutrinal do tema da liberdade religiosa. Pio XI e a Carta Encíclica Non abbiamo bisogno e a Carta Encíclica Mit brennender Sorge. Pio XII, em Nuntius radiophonicus, de 24 de dezembro de 1942, que enumerou os direitos fundamentais da pessoa e suas consequências jurídicas e por fim, a Carta Encíclica de João XXIII Pacem in terris.
} 
Parte-se da intencionalidade com que o tema se desenvolve e a Declaração é redigida, observando as regras teológicas de continuidade e progresso, observadas nos documentos do Concílio Vaticano II que não intencionaram romper com Tradição da Igreja Católica, mas está na perspectiva de renovação nos tempos modernos ${ }^{8}$. Deste modo, distinguem-se três grandes momentos referentes ao processo de evolução histórica do tema: intolerância, tolerância prática e direito à liberdade religiosa. Inferiu-se, portanto, das relações Igrejamundo, a teologia subjacente às definições da Igreja Católica em sua relação com as outras religiões e a sociedade nas distintas épocas. Processo que se conclui no Concílio Vaticano II, com a definição de direito, não mera tolerância, à liberdade religiosa.

Faz-se preciso, portanto, o levantamento do contexto em que ocorreram essas afirmações magisteriais. O período denominado intolerante à liberdade de consciência e religião nos documentos pontifícios promulgados pelos $\mathrm{Pa}-$ pas Gregório $\mathrm{XVI}^{9}$ e Pio IX ${ }^{10}$ caracteriza-se não pela condenação a estas liberdades, mas aquela liberdade religiosa cujo princípio era o indiferentismo religioso estimulado pelo nascente liberalismo estatal e sua oposição à função social e aos valores espirituais da Igreja Católica, o que ocasionou a elaboração de uma doutrina crítica ao Estado e ao processo de laicização e de oposição às novas teorias sociais em seus fundamentos liberais e de indiferentismo religioso. Com isso, condenou-se a ideologia pregada pelos representantes do racionalismo, que fundamentavam a liberdade de consciência unicamente no indivíduo, não estando este sujeito a nenhuma espécie de norma divinamente revelada ${ }^{11}$. Neste ínterim, é relevante ao tema o destaque da atuação de Félicité de Lammenais e de Charles de Montalembert, integrantes de grupos do catolicismo liberal, que ao buscarem a conciliação entre os direitos da Igreja Católica e as liberdades modernas, suscitaram que a Igreja reagisse promulgando documentos que definiam sua compreensão do tema da liberdade religiosa neste contexto ${ }^{12}$.

\footnotetext{
${ }^{8}$ Cf. Ibidem, p. 319.

${ }^{9}$ Cf. DENZINGER, H. Compêndio dos símbolos, definições e declarações de fé e moral, $\mathrm{n}$. 2730-2732.

${ }^{10}$ Cf. Ibidem, n. 2890-2896; 2901-2980. Cf. MARTINA, Giacomo. História da Igreja. De Lutero a nossos dias: A era do liberalismo, v. III. 2. ed. São Paulo: Loyola, 2005, p. 235-239.

${ }^{11}$ Cf. Ibidem, pp. 40-44.

${ }^{12}$ Cf. ZAGHENI, Guido. A Idade Contemporânea: curso de história da Igreja. São Paulo: Paulus, 1999, pp. 30-40. Cf. ALBERIGO, Giuseppe. A Igreja na história. São Paulo: Paulinas, 1999, pp. 269-274.
} 
O início de uma "evolução" na complexa doutrina da liberdade religiosa ocorreu com Leão XIII, Pio XI e Pio XII. Leão XIII, imerso na Questão Romana e consciente de que o poder temporal do papado havia findado, apresentou um projeto de reconciliação entre a Igreja Católica, a cultura ${ }^{13} \mathrm{e}$ o espírito moderno, adaptando-a aos novos tempos ${ }^{14}$. Esta estratégia foi moderada no plano intelectual com a restauração da filosofia cristã por meio do aprofundamento dos estudos neotomistas, que harmonizavam razão e fé ${ }^{15} \mathrm{e}$ favoreciam uma formulação mais objetiva e rigorosa aos documentos do Magistério eclesiástico, "capaz de estabelecer diálogo com o mundo da cultura e da inteligência"16. Neste bojo, compreende-se a nova postura hermenêutica, otimista e de tolerância prática, ao se utilizar da distinção tese e hipótese admitindo a tolerância prática para com as distintas religiões nos Estados, no que se refere à concepção de liberdade religiosa e das liberdades modernas ${ }^{17}$ apresentadas nas Cartas Encíclicas Immortale Dei (1885) e Libertas praestantissimum $(1888)^{18}$.

O contexto dos totalitarismos na Europa caracterizou os pontificados de Pio XI e Pio XII, elevando a um novo estágio a evolução doutrinal e pastoral" 19 o tema da liberdade religiosa. O Tratado de Latrão, em 11 de fevereiro de 1929, encerra a Questão Romana e o Risorgimento italiano, regulando a condição da Igreja Católica na Itália, afirmando-a como religião oficial do Estado e assegurando-lhe o livre exercício do poder espiritual, do culto, da jurisdição eclesiástica e apoio jurídico do Estado. O que não impediu Pio XI de denunciar o clima de exaltação à violência e guerra, fomentado pelo fascismo, defendendo não apenas a liberdade da Igreja, mas "os direitos fundamentais

\footnotetext{
${ }^{13}$ ZAGHENI, G. A Idade Contemporânea: curso de história da Igreja, p. 171. A primeira Carta Encíclica de Leão XIII, Inscrutabili Dei consilio (21/04/1878), trata justamente deste objetivo de seu pontificado: a reconciliação entre Igreja e a cultura.

${ }^{14}$ MARTINS, António Manuel. "Recepção em Portugal das Cartas Encíclicas sobre o Liberalismo: Mirari vos, Quanta cura e Immortale Dei”. Lusitania Sacra/1 (1989), pp. 41-80, p. 65.

${ }^{15}$ Cf. ZAGHENI, G. A Idade Contemporânea: curso de história da Igreja, p. 174.

${ }^{16}$ MARTINS, António Manuel. "Recepção em Portugal das Cartas Encíclicas sobre o Liberalismo: Mirari vos, Quanta cura e Immortale Dei”. Lusitania Sacra 1 (1989), p. 66.

${ }^{17}$ Cf. KLOPPENBURG, B. Concílio Vaticano II, v. 3, p. 320. Cf. MARTINS, A. M. "Recepção em Portugal das Cartas Encíclicas sobre o Liberalismo: Mirari vos, Quanta cura e Immortale Dei”. Lusitania Sacra 1, pp. 67-68.

${ }^{18}$ Cf. MARTINA, G. História da Igreja - De Lutero a nossos dias: III. A era do liberalismo, pp. 244-245.

${ }^{19}$ KLOPPENBURG, B. Concílio Vaticano II, v. 3, p. 321.
} 
da pessoa humana" ${ }^{20}$, ocasionando que "a Igreja ao lutar por sua liberdade, de fato defendesse ao mesmo tempo os direitos naturais do homem, a liberdade do indivíduo e da família diante do Estado"21.

Pio XI dedicou-se ainda a examinar os meios que permitiriam reatar os vínculos entre Oriente e Ocidente cristãos em um empenho exclusivamente unionista, que foi superado no Concílio Vaticano II, com a perspectiva ecumênica e inter-religiosa. A grande contribuição de Pio XII ao tema da liberdade religiosa está em definir a função do Estado de "tutelar o campo intangível dos direitos da pessoa humana" ${ }^{22}$, tema retomado na Declaração Dignitatis humanae. Esse processo histórico de desenvolvimento da doutrina da liberdade religiosa encontra seu desfecho na Carta Encíclica Pacem in terris, paradigmática à compreensão do tema em Concílio por apresentá-lo de maneira atualizada e inserido no contexto maior da tradição católica, oferecendo ainda elementos que foram essenciais à sua definição final ${ }^{23}$. O Papa João XXIII abria a perspectiva do diálogo com o mundo moderno, estabelecendo como fundamento à convivência humana e à relação entre os diversos Estados, a dignidade da pessoa humana ${ }^{24}$. Dignidade esta contemplada "à luz das verdades reveladas" 25 e também sob o princípio de que cada ser humano é pessoa; isto é, natureza dotada de inteligência e vontade livre"26, sendo, portanto,

${ }^{20}$ Cf. MARTINA, Giacomo. História da Igreja. De Lutero a nossos dias: A era contemporânea, v. IV. 3. ed. São Paulo: Loyola, 2014, p. 165.

${ }^{21}$ Ibidem, p. 165.

22 Pio XII. "Radiomensagem na Solenidade de Pentecostes - 50 Aniversário da Carta Encíclica Rerum Novarum de Leão XIII”, 01 de junho de 1941. Disponível em: < http://w2.vatican. $\mathrm{va} /$ content/pius-xii/pt/speeches/1941/documents/hf_p-xii_spe_19410601_radiomessagepentecost.html $>$. Acesso em 28 de outubro de 2015. Cf. KLOPPENBURG, B. Concílio $V$ aticano II, v. 3, p. 322.

${ }^{23}$ Cf. João XXIII. "Carta Encíclica Pacem in terris", 11 de abril de 1963. Disponível em: $<$ http:// w2.vatican.va/content/John-xxiii/PT/encyclicals/documents/hf_j-xxiii_enc_11041963pacem. html $>$. Acesso em 28 de outubro de 2015. No parágrafo 14: "pertence igualmente aos direitos da pessoa a liberdade de prestar culto a Deus de acordo com os retos ditames da própria consciência, e de professar a religião, privada e publicamente"

${ }^{24}$ Cf. Ibidem, n. 7; 30; 35; 36; 79, 11.

${ }^{25}$ Ibidem, n. 9-10. Cf. João Paulo II. "Compêndio da Doutrina Social da Igreja”, 29 de junho de 2004. Disponível em: <http://www.vatican.va/roman_curia/pontifical_councils/justpeace/ documents/rc_pc_justpeace_doc_20060526_compendio-dott-soc_po.html\#top >. Acesso em 11 de outubro de 2016. No número 196, a Igreja Católica manifesta entender que cada homem é “a imagem viva do próprio Deus (...)”, e que justamente por isto, recebeu do próprio Deus uma incomparável e inalienável dignidade.

${ }^{26}$ João XXIII. "Carta Encíclica Pacem in terris", 11 de abril de 1963. Disponível em: <http:// 
dever dos poderes públicos tutelar tais direitos e promovê-los. Dentre estes, está a liberdade religiosa ${ }^{27}$. Este documento, e o Concílio Vaticano II, historicamente se situam em um contexto favorável ao catolicismo, o do fim dos grandes totalitarismos e ascensão da democracia cristã, portanto, da completa superação do liberalismo combativo ou indiferente à religião.

\section{O surgimento de um tema e o estabelecimento de seu fundamento teológico-antropológico: a liberdade religiosa fundamentada na dignidade da pessoa humana}

Neste momento, apresentar-se-á histórica e teologicamente o processo de gênese do tema da liberdade religiosa vinculado ao itinerário de elaboração da Declaração Dignitatis humanae no Concílio Vaticano II. Trata-se do direito à liberdade religiosa a partir da constatação teológico-antropológica da dignidade humana, que se constitui em verdadeiro desenvolvimento doutrinal, expondo cronologicamente as diversas etapas temáticas e redacionais até que se chegue à versão definitiva e que oferece a definição e fundamentação da concepção de liberdade religiosa para Igreja Católica. Este tema, embora não apareça logo de início no Concílio Vaticano II, surge no ano de 1960 no denominado texto de Friburgo ${ }^{28}$, esboço não oficial elaborado por membros do Secretariado para União dos Cristãos e que serviu de base preparatória aos sucessivos esquemas redacionais que antecederam a Declaração final ${ }^{29}$. Três elementos essenciais se mantêm desde esse primeiro esboço: a dignidade humana e a natureza livre da fé exigem respeito e a isenção de coação para boa formação da consciência; os requisitos legais para intervenção estão a encargo do Estado e se pautam no bem comum; deve o Estado reconhecer os direitos da pessoa ao exercício da liberdade religiosa. Deste modo, compreender o processo de gênese e desenvolvimento do tema da liberdade religiosa exige analisar tanto as quatro Sessões conciliares quanto os Períodos Antepreparatório e Preparatório do Concílio Vaticano II. Períodos em que se destaca o

w2.vatican.va/content/John-xxiii/PT/encyclicals/documents/hf_j-xxiii_enc_11041963pacem. html $>$. Acesso em 28 de outubro de 2015. Nos números 9-10.

${ }^{27}$ Cf. Ibidem, n. 14, 27, 65.

${ }^{28}$ Cf. ALBERTI, Vittorio V. "La Dignitatis humanae e la nuova laicità oltre la rivoluzione e la contrarivoluzione". Anuario de História de la Iglesia 21 (2012), p. 310.

${ }^{29}$ Cf. TÉLLEZ, J. A. "Estudio histórico-crítico sobre el derecho a la libertad religiosa en la declaración conciliar Dignitatis humanae". Revista de Derecho de la Pontificia Universidad Católica de Valparaíso 39 (2012), pp. 652-655. 
empenho do Papa João XXIII em conferir ao Concílio o caráter pastoral, fundamental a uma eclesiologia de relacionamento dialogal e servil com o mundo moderno, que supere a perspectiva de um mero convite de retorno aos cristãos "separados" da Igreja Católica ${ }^{30}$. Essencial para o surgimento do tema da liberdade religiosa no Concílio Vaticano II foi também a criação do Secretariado para União dos Cristãos que assegurou um novo caminho ecumênico sob o princípio da liberdade religiosa ${ }^{31}$. Parcela do êxito dos trabalhos do Secretariado se deve aos hóspedes e observadores delegados de outras comunhões eclesiais que, embora não tivessem voz ativa durante os debates e votações, participavam dos trabalhos das comissões e sub-comissões na elaboração dos esquemas garantindo resultados ecumênicos.

O tema da liberdade religiosa não surge de modo abrupto ou metodologicamente previsto pelos esquemas no Concílio Vaticano II, mas durante os debates nas Congregações Gerais e se desenvolvendo nos aspectos formais, significado e fundamentação, e material adquirindo status de Declaração ${ }^{32}$. Relevante ao tema da liberdade religiosa na primeira Sessão conciliar foram os debates sobre o tema da Unidade da Igreja, em que os padres, mediante a discussão sobre os esquemas sobre o Ecumenismo, sobre a Virgem Maria e sobre a Unidade da Igreja, discerniram que há diferença na maneira como se estabelece a relação entre a Igreja Católica e as Igrejas Ortodoxas do Oriente e as Igrejas "dissidentes" do Ocidente, oriundas da Reforma e que um projeto sobre a unidade da Igreja não poderia prescindir dessa diversidade religiosa que abarca a relação entre católicos, ortodoxos e protestantes ${ }^{33}$. Deste modo, a perspectiva estritamente unionista da época de Leão XIII se amplia à dimensão ecumênica. No entanto somente na segunda Sessão do Concílio Va-

${ }^{30}$ Cf. KLOPPEnBURG, B. Concílio Vaticano II, v. 1, p. 23-24; 212-219. Tal caminho é evidenciado no "Schema Decreti de Ecclesiae Unitate: Ut omnes unum sint", apresentado pela Comissão para as Igrejas Orientais, na $28^{\text {a }}$ Congregação Geral. Cf MATTEI, Roberto de. $O$ Concílio Vaticano II. Uma história nunca escrita. São Paulo: Ambiente \& Costumes, 2013, pp. 394-395.

${ }^{31}$ Cf. ALBERIGO, G. (Org.). História dos concílios ecumênicos. São Paulo: Paulus, 1995, pp. 396-400.

${ }^{32}$ Cf. COMBY, Jean. Para ler a história da Igreja: do século XV ao século XX (Tomo II). São Paulo: Loyola, 1994, p. 214. As Declarações, no Concílio Vaticano II, são documentos em que a autoridade eclesiástica vem declarar os princípios e linhas de conduta que expressam o pensamento da Igreja. Assim temos três declarações conciliares: Declaração conciliar sobre a educação cristã, sobre a Igreja e as religiões não-cristãs e sobre a liberdade religiosa, a Dignitatis humanae.

${ }^{33}$ Cf. KLOPPENBURG, B. Concílio Vaticano II, v. 2, pp. 207-231. 
ticano II é que se estabeleceu o princípio da liberdade religiosa à orientação ecumênica, conferindo-lhe uma amplitude inter-religiosa e de diálogo com os ateus e com o mundo contemporâneo.

Os intervalos entre os quatro períodos conciliares são também produtivos e determinantes para os debates, por se constituírem em momentos de reelaboração dos esquemas discutidos durante as Congregações Gerais, adequando-os às emendas sugeridas pelos padres conciliares e por apresentarem iniciativas que estimularam o diálogo entre as distintas tradições religiosas, os sem religião e o mundo moderno, tendo por princípio a liberdade religiosa. Destaca-se a iniciativa de Paulo VI em criar dois novos Secretariados: para as Religiões não Cristãs (1963) e para os Não Crentes (1965). Na segunda Sessão o tema da liberdade religiosa aparece como capítulo cinco do esquema sobre o ecumenismo, tematizado a partir dos debates da $69^{\text {a }}$ Congregação Geral ${ }^{34}$, tendo por expositor padre Emílio De Smedt, que se preocupou em determinar em Concílio o significado conceitual do tema da liberdade religiosa, sua continuidade com a doutrina teológica da Igreja Católica, apresentando quatro razões que fundamentam o direito à liberdade religiosa: razão de verdade, de defesa, de convivência pacífica e razão ecumênica; estendendo-se aos motivos que promovessem o tema a adquirir status de Declaração conciliar ${ }^{35}$. A atualidade e relevância do tema o fazem ganhar espaço nas discussões conciliares.

No período entre 1963-1964, o Secretariado para União dos Cristãos solicitou que o esquema sobre a liberdade religiosa se convertesse em uma Declaração conciliar independente do decreto sobre o ecumenismo. Foi a primeira vez na história da Igreja Católica que um Concílio debateu sobre uma Declaração de tal natureza. Na Terceira Sessão, um novo esquema foi entregue aos padres com o título Declaração sobre a liberdade religiosa. Os debates colaboraram para o amadurecimento do tema, estabelecendo o sentido exato do que é liberdade religiosa ao superar o conceito de tolerância religiosa, apresentando como novidade o direito das comunidades religiosas à liberdade de culto e religião e estabelecendo seus limites: que não haja propaganda desonesta e nada inflija a moralidade pública. Reconhece ainda o caráter laical do poder público, reconhecendo que este não é competente em matéria religiosa e nem pode ser indiferente à religião, atribuindo ao Estado a função de favorecer a vida religiosa que seus cidadãos levam segundo os ditames de sua cons-

\footnotetext{
${ }^{34}$ Cf. ALBERIGO, G. A Igreja na história, pp. 414-415. Cf. O’MALLEY, J. W. O que aconteceu no Vaticano II, pp. 134-135.

${ }^{35}$ Cf. KLOPPENBURG, B. Concilio Vaticano II, v. 3, p. 314-316.
} 
ciência. O grupo conciliar favorável ao tema e a promulgação da Declaração intencionavam o encerramento dos debates e ulterior votação e aprovação do texto já nesta Sessão. No entanto, o grupo dos denominados tradicionalistas, destacando-se o Coetus Internationalis Patrum, idem in re theologica et Pastorali sentientes $^{36}$, exigiu um tempo maior para análise e possível reelaboração do projeto de Declaração, o que de fato ocorreu, ocasionando a extensão dos debates referentes ao tema à quarta Sessão conciliar.

Se anteriormente havia quatro razões que fundamentavam o direito a liberdade religiosa, define-se agora apenas uma: a dignidade da pessoa humana, sujeito livre e responsável que, conforme os ditames de sua consciência tem a responsabilidade de buscar à verdade, sempre de maneira livre e isenta de qualquer tipo de coação ${ }^{37}$. Com isso, a Declaração desvela sua consonância com a doutrina do Magistério eclesiástico dos Pontífices precedentes, acerca dos direitos invioláveis da pessoa humana. Na Relação Oficial explanada por De Smedt, houve a distinção do tema da liberdade religiosa dos temas estritamente teológicos, articulando-o à liberdade civil e jurídica. Para clarificação conceitual, esclareceu-se que não é finalidade da Declaração apresentar os deveres do homem para com Deus ou como deve ser a missão da Igreja Católica, mas determinar a "verdade objetiva" que é a dignidade da pessoa humana, admitida pela teologia e pela racionalidade secular contemporânea, como fundamento do direito à liberdade religiosa. O texto da Declaração Dignitatis humanae foi dirigido não apenas aos cristãos, mas a todos os homens e grupos religiosos. Propôs-se, neste documento, estabelecer a liberdade religiosa em termos jurídicos formais de direito, com argumentos da razão natural e não somente teológico-morais. Isto posto, definiu-se que a liberdade religiosa é um verdadeiro direito, em termos jurídicos, fundado na dignidade da pessoa humana ${ }^{38}$.

${ }^{36}$ Cf. CALDEIRA, Rodrigo Coppe. Os baluartes da tradição: o conservadorismo católico brasileiro no Concílio Vaticano II. Curitiba: CRV, 2011, pp. 179-216. Cf. CALDEIRA, Rodrigo Coppe. "Coetus Internationalis Patrum”. In: PASSOS, João Décio; SANCHEZ, Wagner Lopes (Coordenação). Dicionário do Concílio Vaticano II. São Paulo: Paulus, 2015.

${ }^{37}$ Cf. DENZINGER, Heinrich. Compêndio dos símbolos, definições e declarações de fé e moral, n. 3015-3020. Cf. KLOPPENBURG, B. Concílio Vaticano II, v. 4, p. 319.

${ }^{38}$ Cf. TÉLLEZ, J. A. "Estudio histórico-crítico sobre el derecho a la libertad religiosa en la declaración conciliar Dignitatis humanae". Revista de Derecho de la Pontificia Universidad Católica de Valparaíso 39, pp. 670-678. Cf. O'MALLEY, J. W. O que aconteceu no Vaticano II, p. 330. Cf. O'MALLEY, J. W. O que aconteceu no Vaticano II, p. 330. Cf. MATTEI, R. de. O Concílio Vaticano II, pp. 388-389. Decisiva para a elaboração da Declaração Dignitatis humanae foi a atuação do jesuíta Pe. John Courtney Murray e do Mons. Pietro Pavan, bem como Mons. Emílio De Smedt e do padre Jean J. Hamer. 
Constitui-se a Declaração Dignitatis humanae de um prólogo em que o tema da liberdade religiosa é anunciado em sua exigência e urgência histórica, antropológica e teológica, a primeira parte intitulada "Aspectos gerais da liberdade religiosa", em que o tema é apresentado sob a perspectiva da razão natural ${ }^{39}$, a segunda parte denominada "A liberdade religiosa à luz da Revelação", em que é exposta a fundamentação teológica do tema e a conclusão, em que se exorta à vivência da liberdade religiosa, seja de forma privada seja de modo público, sempre com ordenamento jurídico que garante essa liberdade. Já no número 2 da Declaração é apresentado seu objeto, "a pessoa humana tem direito à liberdade religiosa" ${ }^{40} \mathrm{e}$, em seguida, o fundamento deste direito, "a própria dignidade da pessoa humana"41, que pode ser conhecida pela Revelação divina e também pela razão, enquanto via natural da Revelação, conforme já se designava na constituição dogmática Dei Filius do Concílio Vaticano $\mathrm{I}^{42}$. Em suma, essa Declaração conciliar ao apresentar o tema da liberdade religiosa exige que, em âmbito jurídico, tal liberdade chegue a converter-se em direito civil ${ }^{43}$, garantindo aos cidadãos a liberdade em matéria religiosa e a isenção de coação da consciência. Define o fundamento ontológico do direito à liberdade religiosa: a dignidade humana. Define a função de tutela do Estado e estabelece que, se houver o reconhecimento civil de uma religião como sendo a oficial, que se reconheça o direito à liberdade religiosa de todos os cidadãos. O esquema foi votado e promulgado em 07 de dezembro de 1965, apresentando de maneira muito peculiar a nova eclesiologia de diálogo e serviço da Igreja Católica com as "pessoas de boa vontade" e o novo humanismo desenvolvido em perspectiva cristã pelo Concílio Vaticano II, que expôs a simpatia da Igreja pela situação humana, do homem que pensa, que trabalha,

${ }^{39}$ Cf. TÉLLEZ, J. A. "Estudio histórico-crítico sobre el derecho a la libertad religiosa en la declaración conciliar Dignitatis humanae". Revista de Derecho de la Pontificia Universidad Católica de Valparaíso 39, pp. 687-694.

${ }^{40}$ KLOPPENBURG, B. Documentos do Vaticano II: Constituições, Decretos e Declarações. Petrópolis: Vozes, 1966, pp. 596-597. Cf. WOLFF, E. Unitatis Redintegratio, Dignitatis Humanae, Nostra Aetate: textos e comentários. São Paulo: Paulinas, 2012, pp. 110-111.

${ }^{41}$ KLOPPENBURG, B. Documentos do Vaticano II: Constituições, Decretos e Declarações, pp. 596-597. Cf. WOLFF, E. Unitatis Redintegratio, Dignitatis Humanae, Nostra Aetate: textos e comentários, pp. 110-111.

${ }^{42}$ Cf. DENZINGER, H. Compêndio dos símbolos, definições e declarações de fé e moral, $\mathrm{n}$. 3015-3020. Cf. KLOPPENBURG, B. Concílio Vaticano II, v. 3, p. 319.

${ }^{43}$ Cf. KLOPPENBURG, B. Documentos do Vaticano II: Constituições, Decretos e Declarações, pp. 596-597. Cf. WOLFF, E. Unitatis Redintegratio, Dignitatis Humanae, Nostra Aetate: textos e comentários,p p. 110-111. 
homem de miséria e pobreza, individual e social, homem sagrado que sempre espera algo em Deus ${ }^{44}$.

\section{Desdobramentos contemporâneos do tema da liberdade religiosa}

\subsection{O aventar de uma teologia hermenêutica inter-religiosa}

Esse terceiro item compreende dois desdobramentos histórico-religiosos e jurídicos do tema da liberdade religiosa definido pela Declaração Dignitatis humanae sendo que, algumas questões continuam abertas ao debate, como a possibilidade de uma teologia hermenêutica inter-religiosa e o papel das religiões no espaço público.

O processo de debates que originou e desenvolveu o tema da liberdade religiosa nas Congregações Gerais não se restringiu à elaboração da Declaração Dignitatis humanae e apresentou repercussão em outras Constituições, Declarações e Decretos conciliares ${ }^{45}$. Esta análise oferece os pressupostos estruturantes à dimensão de uma perspectiva dialogante tríplice: ecumênica, inter-religiosa e da Igreja Católica com o mundo, tendo por fio condutor o direito à liberdade religiosa e que incidem na produção teológica, aventando a possibilidade de uma nova teologia das religiões que se configure como teologia do pluralismo religioso. Dado viável na medida em que a o Concílio Vaticano II retoma a doutrina patrística do lógoi spermatikói e, ao articular a Declaração Dignitatis humanae ao Decreto Nostra aetate, identifica doutrinariamente valores positivos presentes em outras tradições religiosas e apresenta a proposta de uma ética do diálogo com as outras religiões ${ }^{46}$. Eis aí o pressuposto teológico necessário à ultrapassagem dos modelos de uma teologia de substituição e do cumprimento, ou do acabamento, subjacente aos documentos do Concílio Vaticano II e constitutivos da teologia das religiões, para a

\footnotetext{
${ }^{44}$ Cf. ZAGHENI, G. A Idade Contemporânea: curso de história da Igreja, pp. 373-376.

${ }^{45}$ Cf. DUPUIS, Jacques. Rumo a uma teologia cristã do pluralismo religioso. São Paulo: Paulinas, 1999, pp. 228-232. Os documentos: Constituição Dogmática Lumen gentium, Constituição Pastoral Gaudium et spes, o Decreto sobre o ecumenismo Unitatis redintegratio, o Decreto sobre as Igrejas Orientais Católicas Orientalium Ecclesiarum, a Declaração sobre a Igreja e as Religiões não Cristãs Nostra aetate e o Decreto sobre a atividade missionária da Igreja Ad gentes, que articuladas à Declaração Dignitatis humanae são proponentes de uma nova postura eclesial dialógica, tendo por fio condutor o direito à liberdade religiosa.

${ }^{46}$ Cf. GEFFRÉ, Claude. De Babel a Pentecostes: ensaios de uma teologia inter-religiosa. São Paulo: Paulus, 2013, pp. 28-37.
} 
elaboração de uma teologia do pluralismo religioso que se configure como teologia hermenêutica inter-religiosa ${ }^{47}$.

Esta teologia, antes de se configurar como novo campo de investigação teológica, tende a se constituir em horizonte possível à reflexão teológica, demonstrando que o tema da liberdade religiosa, enquanto direito fundamentado na dignidade da pessoa humana, articulado à constatação epistemológica de um pluralismo religioso insuperável, que não seja entendido meramente como pluralismo de fato mas de princípio e de direito; em termo teológicos, que seja considerado parte do desígnio salvífico de Deus que se estende a todos, é que pode redefinir a produção da teologia das religiões, configurando-a como teologia do pluralismo religioso, explicitando que esta é uma questão ainda aberta ao debate ${ }^{48}$.

A finalidade da teologia das religiões é, a partir da constatação epistemológica de um pluralismo religioso insuperável, interrogar-se acerca do significado soteriológico do pluralismo religioso no plano de Deus, criando condições a uma eclesiologia que considere seriamente as conseqüências do diálogo inter-religioso. Essa teologia, então, se interessa menos pelas disposições subjetivas dos membros das Igrejas e mais pelos elementos constitutivos das religiões. Destarte, o horizonte dessa forma de pensar teologicamente não se configura em um ecumenismo confessional, mas no "pluralismo religioso" como questão teológica ${ }^{49}$.

Pluralismo religioso que não deve ser visto como fase histórica provisória, superável pela missão da Igreja, mas como fenômeno histórico irreversível e, em termos teológicos, expressão da vontade de Deus. A teologia das religiões não intenta comprometer o cristianismo constitutivo estabelecido pela dogmática magisterial, ou seja, a unicidade soteriológica do mistério de Cristo, o único mediador da salvação. Tenciona, sim, a desabsolutizar o cristianismo como a única religião histórica da salvação. Com isto, compreende-se que "a Verdade" testemunhada pela revelação cristã não precisa ser inclusiva, nem exclusiva a qualquer outra verdade religiosa, mas que seja singular ${ }^{50}$. Destarte, apresenta-se a proposta de um pluralismo inclusivo que reconhece o valor positivo das outras religiões como lhes sendo próprios. De um estreito eclesiocentrismo, parte-se ao reconhecimento do valor das religiões, em sua plu-

\footnotetext{
${ }^{47}$ Cf. Ibidem, pp. 37-57.

${ }^{48}$ Cf. Ibidem, pp. 8-9; 43-49.

${ }^{49}$ Cf. Ibidem, pp. 34-54.

${ }^{50}$ Cf. Ibidem, pp. 58-60.
} 
ralidade e alteridade ${ }^{51}$. A proposta teológica de opção pluralista apresenta não apenas a concepção de um pluralismo de fato, mas ainda de um pluralismo de princípio e de direito ${ }^{52}$. Isto, ao remeter-se ao mistério de uma pluralidade de vias para Deus, que faz parte do "mistério oculto desde os séculos em Deus" e que foi manifesto em Jesus Cristo (cf. Ef 3,9). Deste modo, pode-se considerar o pluralismo religioso como desígnio misterioso e inefável de Deus, cuja significação última escapa à total compreensão humana.

A partir dessa exposição, faz-se possível oferecer os pressupostos fundamentais ao desenvolvimento de um pensar teológico que considere o pluralismo religioso hodierno e a imprescindibilidade do diálogo inter-religioso. Este pensar prospecta no desenvolvimento doutrinal de uma teologia da salvação dos fiéis para uma teologia hermenêutica inter-religiosa ${ }^{53}$, ao reinterpretar a singularidade da mensagem cristã em face dos valores positivos que se encontram nas outras tradições religiosas ${ }^{54}$.

\subsection{A inserção da religião no espaço público}

A constatação de um pluralismo religioso capaz de redefinir a produção teológica em função do profícuo diálogo e práticas inter-religiosas é imprescindível tanto à constituição de uma nova eclesiologia, quanto de um Estado de direito democrático, que imersos em realidade secular, precisam considerar a relevância do fenômeno do pluralismo religioso contemporâneo e o valor da colaboração das diversas tradições religiosas no debate público ${ }^{55}$. O Concílio Vaticano II, na Declaração Dignitatis humanae, apresentou como importante desdobramento do tema da liberdade religiosa a função exigida do Estado, que é a de tutelar e promover, mediante leis justas, os direitos invioláveis do homem, ressaltando o direito à liberdade religiosa de todos os cidadãos e comunidades religiosas, ao providenciar a igualdade jurídica dos mesmos para que não haja qualquer discriminação ou coação em matéria religiosa. A neutralidade do Estado laico é que de fato garante a liberdade religiosa, con-

\footnotetext{
${ }^{51}$ Cf. Ibidem, pp. 54-60.

${ }^{52}$ Cf. Ibidem, p. 50. Cf. TEIXEIRA, Faustino. “A Experiência de Deus nas Religiões”. Numem-Revista de estudos e pesquisa da religião, Juiz de Fora/MG, 3 (2000), pp. 113-115.

${ }^{53}$ Cf. GEFFRÉ, C. De Babel a Pentecostes: ensaios de teologia inter-religiosa, pp. 54-60.

${ }^{54}$ Cf. Ibidem, pp. 37-57.

${ }^{55}$ Cf. SCHULLER, Florian. (Org.). Dialética da secularização: sobre razão e religião, pp. $48-52 ; 82-8$.
} 
ferindo ao cidadão religioso o direito de exteriorizações religiosas na esfera pública que contribuam com os debates públicos. O âmbito dialógico de uma ação comunicativa abarca todos os cidadãos, religiosos ou não, que mediante uma "correlação polifônica" estabelecem mútua purificação entre religião e razão, comportando-se cooperativamente, intencionando a realização do entendimento mútuo, de um consenso obtido comunicativamente e que contribua para manutenção do bem comum no Estado de direito democrático ${ }^{57}$.

A fé cristã e a racionalidade secular engendraram, como nenhuma outra força cultural, a situação contemporânea ${ }^{58}$. Contudo o Estado de direito democrático deve garantir a inserção de outras tradições religiosas e culturais da humanidade no debate acerca das questões básicas da condição humana, que abriga a complementaridade essencial entre religião e racionalidade secular ${ }^{59}$. Nesse âmbito, a interculturalidade e a interdiscursividade democrática são dimensões imprescindíveis por se constituírem em espaço concreto de uma forma legítima de exercício da democracia ${ }^{60}$. A complementaridade essencial entre a fé e a razão colabora para a necessária postura do cidadão, seja ele religioso ou ateu, em um Estado constitucional liberal, uma vez que este Estado supõe a participação do cidadão em termos de colegislador democrático, inferindo desta postura as motivações que engendram e mantém este mesmo Estado liberal ${ }^{61}$.

Ora, essa prática comunicativa, garantida pelo processo democrático, ao estabelecer o entendimento e consenso constitucional, em vista do bem comum, e ao manifestar o empenho dos membros da sociedade para o próprio bem estar, não pode prescindir da contribuição dos concidadãos religiosos nos debates públicos ${ }^{62}$. A integração política dos cidadãos, crentes ou descrentes, da qual depende o Estado, permite às convicções religiosas um status epistêmico que não seja considerado irracional, em termos de conhecimento secular-profano. Ou ainda, que os cidadãos imersos na cultura política liberal

\footnotetext{
${ }^{56}$ Ibidem, pp. 90. A mútua e benéfica correlação entre as possibilidades operativas da razão prática e secular, oriundas de um pensamento pós-metafísico, com a linguagem de fé das distintas tradições religiosas, em função de um mútuo aprendizado que contribua para a constituição do Estado democrático.

${ }^{57}$ Cf. Ibidem, pp. 65-69; 151-152.

${ }^{58}$ Cf. Ibidem, pp. 87-89.

${ }^{59}$ Cf. Ibidem, pp. 82-89.

${ }^{60}$ Cf. Ibidem, pp. 48-52; 82-90.

${ }^{61}$ Cf. Ibidem, pp. 33-35.

${ }^{62}$ Cf. Ibidem, pp. 56-57.
} 
sirvam-se da linguagem religiosa, oriunda dos debates públicos, esforçando-se em traduzi-la para dela inferir as contribuições relevantes, ao torná-las acessíveis publicamente ${ }^{63}$.

Forja-se, deste modo, um processo de aprendizado comum e complementar ${ }^{64}$. Faz-se possível "justificar na filosofia uma disposição para aprendizagem frente à religião, não por razões funcionais, mas por razões de conteúdo" "65. Cabe ao Estado constitucional a transposição dos potenciais de significação conceitual originalmente religiosos, possibilitando a experiência de seu aproveitamento quando aplicados à consciência normativa e à solidariedade dos cidadãos. Em suma, o campo da liberdade civil em matéria religiosa abre espaço para que "ambos os lados estejam em condições de levar a sério em público, por razões cognitivas, as respectivas contribuições para temas controversos" $" 66$.

O tema da liberdade religiosa amplia a relação entre os conteúdos de fé religiosos e o saber secular do mundo, possibilitando que o tríplice diálogo: ecumênico, inter-religioso e com o mundo cultural sociopolítico e econômico moderno e secular seja tutelado pelo Estado, por apresentar o exercício de uma forma legítima de democracia ao desvelar o relevante papel político da religião no espaço público.

\section{Conclusão}

O tema da liberdade religiosa manifesta a importância de se refletir epistemologicamente sobre a profunda relação antropológica da liberdade com a religião e com Deus. No contexto hodierno do pluralismo religioso, o âmbito da religião pode oferecer contributo ao desenvolvimento integral da pessoa humana e para a edificação do bem comum na sociedade, que também depende que as distintas tradições religiosas o favoreçam. Deste modo, o tema da liberdade religiosa é de interesse de todas as pessoas "de boa vontade". Inaugura-se a perspectiva de que a liberdade religiosa é o apogeu de todas as liberdades, que a paz no mundo está vinculada a paz entre as religiões, o que somente ocorrerá quando houver amplo empenho dialógico entre as diferentes tradições religiões, as pessoas "sem religião" e outras de "boa vontade".

\footnotetext{
${ }^{63}$ Cf. Ibidem, pp. 53-57.

${ }^{64}$ Cf. Ibidem, p. 48.

${ }^{65}$ Cf. Ibidem, p. 49.

${ }^{66}$ Cf. Ibidem p. 52.
} 
Contribui ainda para que o homem redescubra a verdadeira arte de viver em um mundo compartilhado com os outros, sejam eles de outras religiões ou sem religião, elevando a dignidade da pessoa humana no reconhecimento da liberdade religiosa, enquanto núcleo essencial dos direitos do homem.

\section{Referências bibliográficas}

ALBERIGO, Giuseppe. A Igreja na história. São Paulo: Paulinas, 1999.

ALBERIGO, Giuseppe (Org.). História dos concílios ecumênicos. São Paulo: Paulus, 1995.

ALBERTI, Vittorio V. "La Dignitatis humanae e la nuova laicità oltre la rivoluzione e la contrarivoluzione". Anuario de História de la Iglesia 21 (2012), pp. 303-320.

Bento XVI. "Discurso aos Cardeais, Arcebispos e Prelados da Cúria Romana na Apresentação dos Votos de Natal”, 22 de dezembro de 2005. Disponível em: <http://migre.me/cb7Im>. Acesso em 28 de outubro de 2015.

Bento XVI. "Exortação Apostólica Pós-Sinodal Ecclesia in Medio Oriente", 14 de setembro de 2012. Disponível em: <http://w2.vatican.va/ content/benedict-xvi/pt/apost_exhortations/documents/hf_ben-xvi_ exh_20120914_ecclesia-in-medio-oriente.html $>$. Acesso em 28 de outubro 2015.

Bento XVI. "Texto inédito publicado por ocasião do $50^{\circ}$ aniversário do Concílio Vaticano II", 02 de agosto de 2012. Disponível em: < http://migre. me/e29PA>. Acesso em 28 de outubro de 2015.

CALDEIRA, Rodrigo Coppe. Os baluartes da tradição: o conservadorismo católico brasileiro no Concílio Vaticano II. Curitiba: CRV, 2011.

COMBY, Jean. Para ler a história da Igreja: do século XV ao século XX (Tomo II). São Paulo: Loyola, 1994.

DENZINGER, Heinrich. Compêndio dos símbolos, definições e declarações de fé e moral. São Paulo: Paulinas: Edições Loyola, 2007.

DUPUIS, Jacques. Rumo a uma teologia cristã do pluralismo religioso. São Paulo: Paulinas, 1999.

GEFFRÉ, Claude. De Babel a Pentecostes: ensaios de uma teologia inter-religiosa. São Paulo: Paulus, 2013. 
João XXIII. Carta Encíclica Pacem in terris, 11 de abril de 1963. Disponível em: <http://w2.vatican.va/content/Johnxxiii/PT/encyclicals/documents/ hf_jxxiii_enc_11041963pacem.html >. Acesso em 28 de outubro de 2015.

João Paulo II. Compêndio da Doutrina Social da Igreja, 29 de junho de 2004. Disponível em: $<$ http://www.vatican.va/roman_curia/pontifical_ councils/justpeace/documents/rc_pc_justpeace_doc_20060526_compendio-dott-soc_po.html\#top >. Acesso em 11 de outubro de 2016.

KLOPPENBURG, Frei Boaventura. Concílio Vaticano II. v. 1-5. Petrópolis: Vozes, 1962-1966.

KLOPPENBURG, Frei Boaventura. Documentos do Vaticano II: Constituições, Decretos e Declarações. Petrópolis: Vozes, 1966.

MARTINA, Giacomo. História da Igreja. De Lutero a nossos dias: A era do liberalismo, v. III. 2. ed. São Paulo: Loyola, 2005.

MARTINA, Giacomo. História da Igreja. De Lutero a nossos dias: A era contemporânea, v. IV. 3. ed. São Paulo: Loyola, 2014.

MARTINS, António Manuel. "Recepção em Portugal das Cartas Encíclicas sobre o Liberalismo: Mirari vos, Quanta cura e Immortale Dei”. Lusitania Sacra 1 (1989), pp. 41-80.

MATTEI, Roberto de. O Concílio Vaticano II. Uma história nunca escrita. São Paulo: Ambiente \& Costumes, 2013.

O’MALLEY, J. W. O que aconteceu no Vaticano II. São Paulo: Loyola, 2014.

PASSOS, João Décio; SANCHEZ, Wagner Lopes (Coordenação). Dicionário do Concílio Vaticano II. São Paulo: Paulus, 2015.

Pio XII. Radiomensagem na Solenidade de Pentecostes - 50 Aniversário da Carta Encíclica Rerum Novarum de Leão XIII, 01 de junho de 1941. Disponível em: <http://w2.vatican.va/content/pius-xii/pt/speeches/1941/ documents/hf_p-xii_spe_19410601_radiomessage-pentecost.html $>$. Acesso em 28 de outubro de 2015.

SCHULLER, Florian. (Org.). Dialética da secularização: sobre razão e religião. São Paulo: Ideias \& Letras, 2007.

TEIXEIRA, Faustino. “A Experiência de Deus nas Religiões". Numem-Revista de estudos e pesquisa da religião, Juiz de Fora/MG, 3 (2000), pp. 111-148. 
TÉLLEZ, J. A. "Estudio histórico-crítico sobre el derecho a la libertad religiosa en la declaración conciliar Dignitatis humanae". Revista de Derecho de la Pontificia Universidad Católica de Valparaíso 39 (2012), pp. 639-70.

WOLFF, Elias. Unitatis Redintegratio, Dignitatis Humanae, Nostra Aetate: textos e comentários. São Paulo: Paulinas, 2012.

ZAGHENI, Guido. A Idade Contemporânea: curso de história da Igreja. São Paulo: Paulus, 1999.

Paulo Sérgio Lopes Gonçalves Doutor em Teologia pela Pontificia Università Gregoriana (Roma, Itália) Pós-doutor em Filosofia pela Universidade de Évora (Portugal) Professor na Pontifícia Universidade Católica de Campinas Campinas / SP - Brasil E-mail: p_aselogo@hotmail.com

Alexandre Boratti Favretto Mestre em Ciências da Religião pela PUC-Campinas Campinas / SP - Brasil E-mail: oalebf@yahoo.com.br

Recebido em: 30/12/15

Aprovado em: 25/04/16 